\title{
TOURISM SECTOR IN TRANSITION ECONOMY ON EXAMPLE OF UKRAINE: DETERMINANTS OF COMPETITIVENESS
}

\author{
Mariana KOLOSINSKA* \\ Yuriy Fedkovych Chernivtsi National University, Department of Economics and Security of the \\ Enterprise, 2 Kotsyubynsky Str. Chernivtsi 58012, Ukraine, e-mail: m.kolosinska@chnu.edu.ua
}

\section{Oksana PETRASHCHAK}

Yuriy Fedkovych Chernivtsi National University, Department of Business, Trade and Stock Activity, 2 Kotsyubynsky Str. Chernivtsi 58012, Ukraine, e-mail: petrashchak.oksana@gmail.com

\section{Ievgen KOLOSINSKYI}

Chernivtsi Institute of Trade and Economics of KNTEU, Department of Finance, Banking and Entrepreneurship, 7 Tsentralna Square, Chernivtsi 58002, Ukraine, e-mail: safe_cv@ukr.net

\begin{abstract}
Albina KATANA
Chernivtsi Institute of Trade and Economics of KNTEU, Department of Finance, Banking and Entrepreneurship, 7 Tsentralna Square, Chernivtsi 58002, Ukraine, e-mail: albinakatana1@gmail.com
\end{abstract}

Citation: Kolosinska, M., Petrashchak, O., Kolosinskyi, I., \& Katana, A., (2018). TOURISM SECTOR IN TRANSITION ECONOMY ON EXAMPLE OF UKRAINE: DETERMINANTS OF COMPETITIVENESS. GeoJournal of Tourism and Geosites, 21(1), 239-252. https://doi.org/10.30892/gtg.21119-284

\begin{abstract}
The aim of the research is to justify the possibility of using and benefits of Porter Diamond Model to improve the competitiveness of the tourism industry in transition economy. Porter Diamond Model was a tool applied for the competitiveness level evaluation of the tourism sector in transition economy on example of Ukraine. This article expands the scope of the "rhomb" model of Porter (1990) to identify the braking and stimulating factors of competitiveness, which will increase the competitiveness of the tourism sector in the transition countries by enhancing the stimulating factors and removing the braking ones. This approach allowed defining the present competitiveness level and the potential ways of its improvement. Specific suggestions were developed on removing the inhibition factors and strengthening the stimulating ones to increase the competitiveness of the tourism sector of Ukraine.
\end{abstract}

Key words: tourism sector, competitiveness of tourism sector, Porter Diamond Model, factors of competitiveness, transition economy, Ukraine

$$
* \quad * \quad * \quad * \quad * *
$$

\section{INTRODUCTION}

The problem of economy modernization and enhancing national competitiveness are among the main priorities of the social-economic reform in transition economies. The purpose of structural modernization should be the construction of a highly effective

\footnotetext{
${ }^{*}$ Corresponding author
} 
competitive dynamic socially oriented economic system in which development is ensured primarily through expanding the use of innovative technologies, rational use of human potential, increasing and improving the quality level of export potential and integration into world economic relations, expansion of capacity and balance of the internal market. The changes in the structure of the modern world economy are characterized by a decrease in the specific weight of the productive sectors and the growing share of services. On the other hand, the increase of public incomes and needs of the citizens determines the demand for specific services associated with leisure activities, travelling, cultural and educational queries, rehabilitation and recreation, etc. This leads to the accelerated development of the tourism sector at the present stage of social development. So, tourism industry is the largest service industry and largest employment generator in the world (Tuzunkan, 2018). But in the current situation in the tourism sector of countries with transitional economies it is noted that the formation of a competitive tourism industry with its further integration into the world market of tourist services is connected with the necessity for effective measures to intensify the production of a competitive tourist product of appropriate quality and to identify and overcome the problems that hamper its development. That is why the development of alternative tools for studying the competitiveness of the tourism industry in order to strengthen it is relevant and timely.

A look at recent literature shows that there have been a number of significant studies with regard to competitiveness in the tourism sector. Gooroochurn and Sugiyarto (2004) have worked a model for assessing the competitiveness of tourist destinations, whose units of analysis were: (I) prices; (II) economic openness; (III) technological developments; (IV) structure; (V) human development in the tourism sphere; (VI) social development; (VII) environment, and (VIII) human resources.

Melián-Gonzáles and García-Falcón (2003) have also drawn up a model for the evaluation of competitiveness, and have applied it empirically to a segment of fishing tourism in the Canary Islands, in Spain. According to these authors, the resources of tourist destinations can be described as consisting of natural resources (beaches and mountains) or cultural resources (museums, festivals, local traditions etc.).

Enright and Newton (2004) has proposed a comprehensive approach that adds industry-level competitiveness attributes to more conventional tourism destination attributes. This study builds on these ideas by generating sets of both attributes, developing a methodology for assessing their relative importance and examining the degree to which their relative importance varies across locations.

Barbosa et al., (2010) presented the methodology of the 'Study of competitiveness of 65 key destinations for the development of regional tourism' prepared by the Tourism Ministry, the Brazilian Support Service to Micro and Small Enterprises (Sebrae) and Getulio Vargas Foundation (FGV). It was structured into 13 different aspects, which we have called dimensions, subdivided into 60 variables guided by ex-ante evaluation criteria (efficiency), the units of analysis of which are of a systemic or structural nature, depending on the nature of each variable. This combination of components was the base for the construction of a model for the measurement of competitiveness of the 65 key destinations, which also included rigorous control over the collection and analysis of data, seeking to capture the reality of each of the tourist destinations as accurately as possible.

The model of Ritchie and Crouch (2010) is the most well-known conceptual model of destination competitiveness and sustainability in tourism literature. In the last interpretation, it contains 7 elements, which according to the authors' opinion, provide the competitiveness of the tourism industry. These components are: The global (macro) 
environment; The competitive (micro) environment; Core resources and attractors; Supporting factors and resources; Destination policy, planning and development; Destination management; Qualifying and amplifying determinants.

The World Economic Forum (WEF) published a significant study on competitiveness first in 2007, based on the Tourism and Travel Competitiveness Index (TTCI) developed by the World Economic Forum experts in cooperation with Booz and Company, Deloitte, International Air Transport Association, International Union for the Conservation of Nature, World Tourism Organization UNWTO and the World Travel and Tourism Council. TTCI allows to identify the barriers to the successful development of the tourist industry at the national level and to develop specific measures to improve the competitiveness of countries in the world market of tourist services.

Today (WEF, 2015), structurally, TTCI consists of four subindexes, which in turn contain 14 groups of indexes (pillars) that combine factors characterizing the multi-vector sides of the development of the tourism sector. The Enabling Environment subindex, which captures the general settings necessary for operating in a country: 1. Business Environment 2. Safety and Security 3. Health and Hygiene 4. Human Resources and Labour Market 5. Information and Communication Technologies (ICT) Readiness. The Travel \& Tourism (T\&T) Policy and Enabling Conditions subindex, which captures specific policies or strategic aspects that impact the T\&T industry more directly: 6 . Prioritization of T\&T 7. International Openness 8. Price Competitiveness 9. Environmental Sustainability. The Infrastructure subindex, which captures the availability and quality of physical infrastructure of each economy: 10. Air Transport Infrastructure 11. Ground and Port Infrastructure 12. Tourist Service Infrastructure. And the Natural and Cultural Resources subindex, which captures the principal "reasons to travel": 13. Natural Resources 14. Cultural Resources and Business Travel.

Among the Ukrainian scientists, it is worth noting the work: (Mihuschenko, 2013), in which, in order to increase the tourism sector's competitiveness was proposed a comprehensive multilevel methodology for assessing the competitiveness of the tourism industry of Ukraine at different levels of the management hierarchy.

To summarize, it is worthwhile to note that the research and evaluation of competitiveness of the tourism sector is the main topic in the works of such Ukrainian scientists as: (Bejdyk, 2001; Hrynkevych \& Biel, 2009; Tkachenko, 2010). It should be noted that despite the extensive theoretical and methodological study of tourism competitiveness, a unified methodology is still not created for the evaluation of this phenomenon for the country. First of all, this is because the majority of scientists, including (Hrynkevych \& Biel, 2009; Bezugla, 2004), focus their attention on assessing the competitiveness of a tourism product of the region, or consider in their research methods for assessing certain aspects affecting the development of tourism competitiveness of a country or contiguous processes within the limits of investment attractiveness, etc. That is why, with the increasing influence of the tourist services sphere on the world economy, there is a justified necessity in the comprehensive study of the competitive advantages of the country's tourism industry.

Since the most significant contribution to the study of problems of countries' competitiveness was made by Porter (1990), the author of the competitive advantage theory, according to which a country achieves high competitiveness not in all sectors of the economy, but only in those in which it has competitive advantages, he proposed the concept of "international competitiveness of Nations".

According to M. Porter, the country's competitiveness in international exchange is determined by the influence and interconnection of the following four main components: factor conditions; demand conditions; the state of servicing and related industries; firm's 
strategy in a particular competitive environment. We believe that in order to formulate proposals for ensuring the competitiveness of the tourism sector in the country it is expedient to use the M. Porter's "rhombus" model of the country's competitiveness in order to determine the inhibitory and stimulating factors of competitiveness, which will allow to increase the competitiveness of the tourism sector of countries with economies in transition by strengthening incentive factors and eliminating the braking ones.

This model was used in research project report by Wahogo (2006) to apply the Porter Diamond model in analysing the competitiveness of Kenya's tourism industry. Curta (2016) have done a summary of the analysis made using the model of "diamond" designed by Michael Porter, about the Romania's situation in tourism sector. Koskovetskaya and Skorobogatova (2016) substantiated the expediency of using M.Porter's model for assessing the industry's competitiveness in the context of integration processes, proving the need for the inclusion of an additional determinant "the activity of international business". On the other hand, some experts have accused M. Porter failing elements in its model, such as national culture, considered to be essential for the competitive advantage of European nations (Bosch \& Prooijen, 1992). The purpose of our paper in the theoretical part is to substantiate the feasibility of using Porter's diamond model in order to assess the competitiveness of the tourism sector in transition economies and to identify the main ways of enhancing it by the application of this model. In the further part (empirical) of this article we will apply Diamond model to the Ukrainian practice in order to determine the conditions of competitiveness of the tourism sector in transition economies, outlining the factors influencing them and finding ways to solve the main problems of the tourism sector.

\section{THEORETICAL FRAMEWORK}

Taking into account that the purpose of this article is to use the Porter Diamond Model as a tool for studying the competitiveness of the tourism sector in transition economies, it is advisable to consider this method in more detail. M. Porter conducted a four-year study of ten countries that occupy an important place in world trade in order to find out why countries are gaining competitive advantage in one or another field, and to find initial positions of the policy of enterprises and of the national economy.

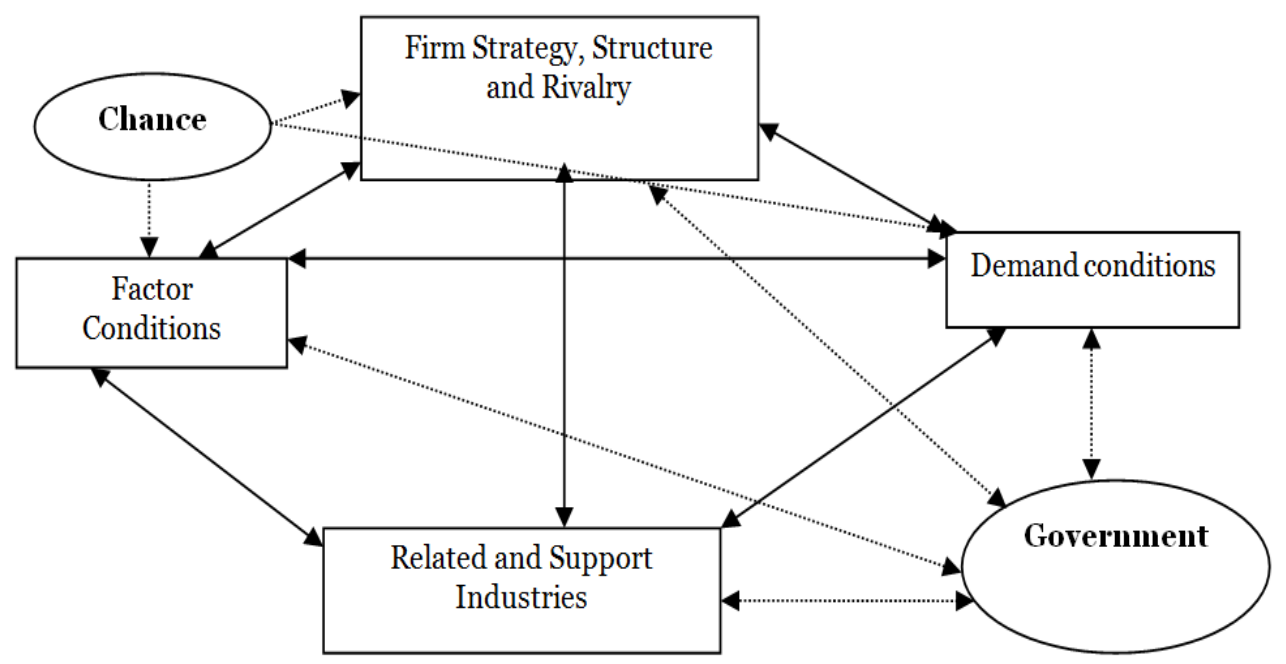

Figure 1 Determinants of the competitive advantage of the country (Source: Porter, 1998, p. 127) 
Developed as a result of the study, a comprehensive theory of competitive advantage of countries, which is supported by a sufficient number of facts, is considered in his fundamental work, The Competitive Advantage of Nations, by M. E. Porter (1990). M. Porter defines four main elements of national competitiveness (determinants) (Figure 1).

It should be considered in detail each of the elements, as well as their features in terms of tourism Factor conditions are characterized by the following features: the availability of factors, their hierarchy and creation. The second determinant is the demand conditions, i.e. the demand in the internal market for the products or services offered by the industry. Demand conditions are characterized by: structure; the volume and nature of growth; internationalization. The third determinant of national competitive advantage is the availability of related and support industries in the country that are competitive in the international market. Related are those industries in which firms can interact with each other in the process of forming a chain of values and the industries that produce complementary goods (substitutes). The access to information exchange and technical cooperation is provided by the presence in the country of related industries capable of competing in the world market.

And geographical proximity and cultural affinity contribute to a more active and a quick exchange than with foreign firms. Concerning the tourism industry such can be considered light, food, transport and hotel industry. The fourth determinant is firm strategy, structure and rivalry, that is, the conditions in a country that determine how firms are formed and managed, and the nature of competition in the internal market. These national characteristics have a significant impact on the position of enterprises when targeting on global competition.

In addition to the mentioned determinants, Porter adds two more factors to his model: chance and government. Under chance, he understands those circumstances that were not foreseen as those that will affect the determinants of the "diamond" model. For the tourist market they can include the following factors, for example: the latest technological advances in the tourism sector; significant fluctuations in exchange rates (for example, the revaluation of the national currency contributes the reduction of incoming tourist flows); changes in visa legislation of foreign countries and etc.

The government's role in the formation of national advantages lies in the fact that is that it has the ability to influence each of the determinants:

- on the factor conditions - through subsidies, grants, preferential credit terms for tourism enterprises, aimed at inbound tourism, the use of preferential taxation, etc.;

- on the demand conditions - by setting conditions for standardization and certification of tourist services; promotion of social and rural tourism; increase of real wages of the population as the basis for further payment of rest and tourist services;

- on the conditions of development of related and supporting industries - by supporting industries and productions - suppliers of goods and services for tourism enterprises;

- on the firm strategy, structure and rivalry of travel agencies - through tax policy, antimonopoly legislation, through regulation and stimulation of investments, the introduction of visa-free regime, etc.

Thus, the determinants of national competitiveness in the tourism sector are a set of interrelated factors that affect a country's competitiveness in the tourism sector. Therefore, in order to outline the level of competitiveness of the country's tourist sector, it is necessary to determine where the components of the national "rhomb" ("diamond") are mutually reinforcing. It is important that the advantages of each determinant do not ensure the country's absolute competitiveness in the tourism sector, but the interaction of the advantages of all determinants creates conditions for the development of a competitive tourist market of the country on a global scale. 


\section{METHODOLOGY}

This research has been based on the following steps. Firstly, we determined the competitiveness of the tourism industry in a country with a transition economy applying the Porter Diamond Model. Thereby, using the Porter Diamond Model for a separate country with a transition economy, we will be able to analyze the stimulating and braking factors of the competitiveness of Ukraine's tourism sector in the international tourism market by assessing four determinants defined in the Porter's model. The stimulating factors are those that shape the country's competitiveness for each of the four determinants. The braking factors of competitiveness of the country's tourist industry will include those that are available but need to be revised to achieve the country's competitiveness on the international tourist market. Secondly, two additional factors of the model were evaluated: chance and government, and, thirdly, we identified ways to enhance influence of stimulating factors and eliminate braking factors.

Such comprehensive analysis will ensure the maximum predictability of development after the proposed solutions application.

\section{DISCUSSION AND RESULTS}

\begin{tabular}{|l|l|}
\hline \multicolumn{2}{|c|}{ Government } \\
\hline \multicolumn{3}{|c|}{ Factors of competitiveness of Ukraine } \\
in the tourism sector
\end{tabular}

Figure 2. Stimulating and braking factors of Ukraine's competitiveness in the tourism sector (Source: Porter's - 1998 competitiveness theory) 
Porter's "diamond" model of competitiveness (Porter, 1998) is considered and applied to the Ukrainian practice in order to determine the conditions of competitiveness of the tourism sector in transition economies, outlining the factors influencing them and finding ways to solve the main problems of the tourism sphere.

On the basis of this model, we determined the stimulating and braking factors of the competitiveness of Ukraine's tourism sector in the international tourism market by assessing four determinants defined in the Porter's model. The system of stimulating factors for increasing the competitiveness of national tourism products and factors that slow down Ukraine's exit on the world tourist market are shown in Figure 2. It is necessary to consider the determinants shown in the picture in more detail.

Factor conditions in the tourism sector of Ukraine there is a saturation of the labor market, but the qualification level of the involved specialists in tourism still does not meet the world standards. It is important that Ukraine has a significant tourist and recreational potential, which includes the natural-resource potential (climatic, marine, balneological, recreational and other resources) and the existence of a historical and cultural heritage, but this potential is used in Ukraine only by 7 - 9\% (Shulgina, 2005, p.24). Recreational resources of Ukraine make up 9.5\% of the total natural resource potential of the country, but their use is considered as a source in economic development of the state for the future. The presence of historical and cultural potential is important because the vast majority of foreign tourists want to get new impressions and cognitive information from the trip. After gaining independence, more than 140 thousand immovable monuments of history and culture have been transferred to state protection. But the conservation and rational use of such an inheritance requires systematic and purposeful actions by the state and the public.

In our opinion, solving the problem of rational use of cultural-historical heritage is possible after the following actions:

1. The increase and rational allocation of budgetary expenditures on culture to $2 \%$ of the state budget, and 3-4\% of the local level budget, according to the justified European experience.

2. The transfer of comprehensive state management of the protection, use and restoration of the cultural heritage to a separate body of public administration. This could be State Committee for the protection of historical and cultural heritage or the Department of cultural heritage protection within the Government. This possibility is provided by Article 3 of the Law of Ukraine "On the Protection of the Cultural Heritage".

3. Harmonization of legal norms between the legal documents concerning the protection of monuments and those which regulate the relations of ownership.

4. Introduction of incentives from the state to attract private funds. Based on international experience, we propose the introduction of a system of tax incentives for property owners who are registered in the national register on a permanent basis. In particular, we propose to introduce a tax allowance of $25 \%$ on investment in restoring historic buildings. Also, to transfer the expendable objects of cultural-historical heritage in long-term lease (up to 50 years) to private owners for their profit from tourism business. But at the same time outlining the strict observance of a number of important conditions, in case of non-fulfillment of which the state reserves the right to immediately return the monument and to recover from the former tenant significant penalties.

5. Take measures to reduce the number of so-called "black archaeologists" in Ukraine. Uncontrolled tourism can bring damage to both nature and culture (Cappucci, 2016). An effective solution of this problem may be the development of archaeological tourism, involvement in the excavation of amateurs under the leadership of specialists, cooperation in this field of academic institutions. 
There is also a lack of information resources, that is, a set of scientific, technical and popular information that influences the formation of a tourism product of the country. This is confirmed by the fact, that in 2013 the brand of Ukraine as a tourist country was on the 109th spot, according to the WEF (2013, p. 347). This factor is also characterized by insufficient number of printed and electronic literature of an advertising character. There is no publication in our country that would promote the tourist product of Ukraine inside the country and abroad. The editions "International tourism", "World of tourism", "Ukrainian tourism" focuses their attention first of all on advertising field trips. The exception is the magazine "Carpathians Tourism Rest", which is highly specialized and introduces attractive places in Transcarpathia, as well as the periodical" Welcome to Ukraine ", which meets the needs of the market and is published simultaneously in two languages (Ukrainian and English). Prospects for the effective development of the tourism industry in Ukraine are related with the formation of appropriate information, scientific and technical support of this area, which at the national and regional levels should be associated with the activation of the following areas:

- development of application programs for the development of the nature management, promotion and realization of tourist product;

- development of inventory of tourist resources;

- development of a complex of scientific knowledge in the field of tourismology and tourism management;

- development and publication of manuals and directories (tourist routes, places of rest, food, etc.);

- creation of rating of all travel companies of Ukraine on the quality indicator of fulfilled obligations;.

- development of automated booking and reservation systems.

In Ukraine, the advantageous geographical location of the country is not supported by the infrastructure on the corresponding level. The main obstacles to the development of Ukraine's tourist infrastructure are poor road quality and unjustified price policy in the hotel industry. In our opinion, the following measures will have priority for infrastructure development:

- integration of Ukraine into a single European railway network, which involves the country's inclusion in the European program for the construction of high-speed railways (speed - 200-300 km / h);

- participation of our country in the network of strategic transport corridors of Central and Eastern Europe;

- attraction of funds by international credit programs at a rate of 5-7\% per annum;

- ensuring the possibility of free treatment of insured tourists in city hospitals and clinics;

- introduction of innovations in the development of tourism infrastructure;

- organization of tenders and targeted investment competitions for the right to reconstruct and build new tourism objects.

The most problematic for ensuring the competitiveness of tourism in Ukraine, both on the internal and foreign markets is insufficient amount of money resources that are involved in the development of tourism. In our opinion, the main source of funds for tourism should be external and internal investment resources. Nowadays, according to the State Statistics Service of Ukraine, in 2016 the amount of capital investment by tourism enterprises made up UAH $2447.8 \mathrm{mln}$. which was $0.68 \%$ of the total volume of the country; in 2015 - UAH $2466.7 \mathrm{mln}$. (0.9\% of the total volume) (Table 1).

In the end, during 2010-2015, the weight of capital investments developed by enterprises of the tourism industry in Ukraine amounted to an average of $1.18 \%$ of the total volume in the country. It is clear that this level is insufficient, taking into account global indicators according to the World Tourism and Travel Council (WTTC) (2016) 
tourism accounts for $4.3 \%$ of total investment. That is why it is currently relevant to apply tax incentives for the development of the tourist industry, which are used in most European countries. In our opinion, all the instruments of tax incentives can be divided into 3 groups, the characteristics of which are given in Table 2.

Table 1. Capital investment developed by enterprises of the tourism sector in 2010-2016 (Source: calculated by authors based on data from State Statistics Service of Ukraine (Capital investment in Ukraine, 2010-2016)

\begin{tabular}{|l|c|c|c|c|c|c|c|}
\hline \multicolumn{1}{|c|}{ Indicator } & 2010 & 2011 & 2012 & 2013 & 2014 & 2015 & 2016 \\
\hline 1. Capital investment, all in Ukraine, mln.USD & 22571.9 & 30160.8 & 34157 & 31234.2 & 18284.9 & 12414.4 & 13816 \\
\hline 2. Capital investment in tourism, mln.USD & 251.2 & 376.25 & 607.9 & 510.4 & 168.5 & 112.1 & 94.1 \\
\hline $\begin{array}{l}\text { 2.1. Temporary placement and } \\
\text { organization of food, mln.USD }\end{array}$ & 129.2 & 196.6 & 283.1 & 184.6 & 123.5 & 63.3 & 56.8 \\
\hline Temporary placement, mln.USD & 84.9 & 126.4 & 191.8 & 109 & 72.3 & 40.5 & 29.1 \\
\hline Providing food and drink, mln.USD & 44.3 & 70.2 & 91.3 & 75.6 & 51.2 & 22.9 & 27.8 \\
\hline $\begin{array}{l}\text { 2.2. Arts, sports, entertainment and } \\
\text { recreation, mln.USD }\end{array}$ & 122.1 & 179.7 & $\begin{array}{c}324 . \\
8\end{array}$ & 318.1 & 42.4 & 47.5 & 37.3 \\
\hline $\begin{array}{l}\text { 2.3. Activities of travel agencies, tourist } \\
\text { operators, mln.USD }\end{array}$ & $\mathrm{n} / \mathrm{d}$ & $\mathrm{n} / \mathrm{d}$ & $\mathrm{n} / \mathrm{d}$ & 7.7 & 2.6 & 1.33 & $\mathrm{n} / \mathrm{d}$ \\
\hline $\begin{array}{l}\text { 3. Share of capital investments developed } \\
\text { by tourism enterprises in Ukraine to the total } \\
\text { volume of investments in the country,\% }\end{array}$ & 1.11 & 1.25 & 1.78 & 1.63 & 0.92 & 0.9 & 0.68 \\
\hline $\begin{array}{l}\text { 5.1. Share of capital investments, which were } \\
\text { developed by enterprises from temporary } \\
\text { placement and organization of food to the } \\
\text { total volume of investments in the country,\% }\end{array}$ & 0.57 & 0.65 & 0.83 & 0.59 & 0.68 & 0.51 & 0.41 \\
\hline $\begin{array}{l}\text { 5.1. Share of capital investments, developed } \\
\text { by the enterprises of the sphere of art, } \\
\text { sports, entertainment and recreation to total } \\
\text { volume of investments in the country,\% }\end{array}$ & 0.54 & 0.6 & 0.95 & 1.02 & 0.23 & 0.38 & 0.27 \\
\hline $\begin{array}{l}\text { 5.1. Share of capital investments, developed } \\
\text { by travel agents and tour operators to the } \\
\text { total volume of investments in the country,\% }\end{array}$ & $\mathrm{n} / \mathrm{d}$ & $\mathrm{n} / \mathrm{d}$ & $\mathrm{n} / \mathrm{d}$ & 0.02 & 0.01 & 0.01 & $\mathrm{n} / \mathrm{d}$ \\
\hline
\end{tabular}

The result of the introduction of the tax incentives in Table no. 2 for Ukraine is the increase of tourism development indicators, significant amounts of attracted foreign investment, as well as integration into the world community and the admission of Ukraine to the leading tourist countries. Summing up this part of the study, we note that the factors considered differ, depending on whether they are naturally or artificially created. In Ukraine the basis of the competitiveness of the tourism sector form most naturally created factors, and according to M. Porter, the factors contributing to the achievement of competitive advantages of a higher level are artificial. That is why for our country is actual the development of tourism infrastructure by attracting both internal and foreign investment money resources.

The next determinant of national competitive advantage is the demand on the internal market for tourist services. According to the WTTC (2016), over the past three years, the number of foreign tourists who visited Ukraine has decreased by five times. According to the Statistics Service of Ukraine for 2013-2016, the analysis of recent trends indicates a decrease in interest in domestic tourist trips and a decrease in the number of foreign tourists. The sharp decline occurred in 2013, which is explained by the occupation of the Autonomous Republic of Crimea. The downward trend of inbound tourist flow is preserved until today. 
Table 2. Characteristics of tax incentives for tourism industry in Ukraine (Source: made by authors based on Dovbenko, 2007)

\begin{tabular}{|c|c|c|}
\hline $\begin{array}{c}\text { Types of } \\
\text { incentives }\end{array}$ & Characteristic & World experience of application \\
\hline 1 & 2 & 3 \\
\hline $\begin{array}{l}\text { Reduced } \\
\text { VAT rates }\end{array}$ & $\begin{array}{l}\text { Exemption from VAT in the field of } \\
\text { inland and outbound tourism; } \\
\text { Application of a reduced rate of VAT for } \\
\text { hotels and other accommodation } \\
\text { establishments that have been certified } \\
\text { for compliance with a particular } \\
\text { category. }\end{array}$ & $\begin{array}{l}\text { In Poland the tax rate is } 7 \% \text {; } \\
\text { In Croatia, the value added tax (VAT) for } \\
\text { most goods and services is } 22 \% \text {, but } \\
\text { travel services (hotel accommodation) are } \\
\text { exempt from paying this tax; } \\
\text { Germany and Luxembourg set the } \\
\text { average VAT rate of } 15 \% \text {; In Greece, VAT } \\
\text { on the accommodation of tourists and } \\
\text { their food is } 8 \% \text {. }\end{array}$ \\
\hline $\begin{array}{l}\text { Tax } \\
\text { privileges }\end{array}$ & $\begin{array}{l}\text { Providing "tax holidays" to business } \\
\text { entities engaged in the reconstruction } \\
\text { of tourist facilities for the period of } \\
\text { these works; Development of state } \\
\text { guarantees of return on investment; } \\
\text { Measures to reduce the percentage of } \\
\text { the loan up to } 5-7 \% \text {; The practice of } \\
\text { free (preferential) connection of } \\
\text { tourist institutions to all types of } \\
\text { communications; } \\
\text { Introduction of long-term lease of land } \\
\text { with preferential payment for tourist } \\
\text { objects; Customs privileges for the } \\
\text { import of equipment for hotels and } \\
\text { tourist vehicles; The absence of tax } \\
\text { penalties for entities that start } \\
\text { establishing green tourism for the first } \\
5 \text { years. }\end{array}$ & $\begin{array}{l}\text { In Hungarian legislation, the regulation } \\
\text { of "green-tourism" relations is not } \\
\text { subject to regulatory acts that regulate } \\
\text { business relations; } \\
\text { The government of Cyprus leases land } \\
\text { for } 99 \text { years with the possibility of } \\
\text { further extension of the lease for the } \\
\text { same term for the construction of new } \\
\text { tourist facilities; } \\
\text { In Spain and Greece, investors are } \\
\text { granted preferential tax treatment and } \\
\text { depreciation rate, reduced turnover tax; } \\
\text { In Greece is developed a system of } \\
\text { discounts for travel agencies that receive } \\
\text { reception in the off-season period; } \\
\text { Slovakia implements the Tourism } \\
\text { Development Support Program, which } \\
\text { provides for partial state subsidies for the } \\
\text { restructuring of tourist infrastructure and } \\
\text { the Credit Support Program for the } \\
\text { implementation of tourism infrastructure } \\
\text { development projects. }\end{array}$ \\
\hline $\begin{array}{l}\text { Creation } \\
\text { of special } \\
\text { economic } \\
\text { zones of } \\
\text { tourist- } \\
\text { recreation } \\
\text { al type } \\
\text { (SEZ TR) }\end{array}$ & $\begin{array}{l}\text { Foreign trade privileges: preferential } \\
\text { customs regime, exemption from } \\
\text { import duties, free movement of foreign } \\
\text { currency abroad; Fiscal privileges: } \\
\text { lower tax rates on import of raw } \\
\text { materials and income tax, partial } \\
\text { exemption from corporate taxation; } \\
\text { Financial privileges: granting of } \\
\text { preferential long-term loans, delayed } \\
\text { payment of VAT when importing new } \\
\text { equipment, components and materials, } \\
\text { that are not produced in Ukraine; } \\
\text { Administrative privileges: minimizing } \\
\text { bureaucratic procedures, permission to } \\
\text { buy land by foreign citizens. }\end{array}$ & $\begin{array}{l}\text { The Government of Tunisia has allowed } \\
\text { foreign investment in tourism without } \\
\text { any restrictions; } \\
\text { The OAU has been given the opportunity } \\
\text { for foreign citizens to have } 100 \% \\
\text { ownership of the existing company in the } \\
\text { SEZ, and simplified the procedure of } \\
\text { obtaining visas for owners and employees } \\
\text { of the company; } \\
\text { In Antalya (Turkey) is granted a } \\
\text { preferential corporate taxation is (30- } \\
100 \% \text { ), the income tax is granted from } 30 \\
\text { to } 100 \% \text { and the government provides } \\
50 \% \text { of preferential loans from the total } \\
\text { investment of firms in marketing, } \\
\text { research and development of tourism, } \\
\text { environmental protection. }\end{array}$ \\
\hline
\end{tabular}


Instead, the share of domestic tourists to the total number of tourists served by the subjects of tourist activity of Ukraine has started to increase, but has not reached the number of 2013 and is equal to $17.7 \%$ in 2015; 2013-20.3\% (Tourist Streams, 20002015). The low proportion of domestic tourism flows is a deterrent, as demand in the domestic tourism market outlines the prospect of introducing innovations and the development of inbound tourism. The main directions of demand structure in the domestic market are West Ukrainian and Kyiv directions. Positive is that the structure of the inbound tourist flow is almost identical, which should stimulate the direction of the investment resource in the tourism sector. Today, domestic tourist flows do not influence the formation of elite tourism in Ukraine, as a solvent consumer in most cases prefers foreign tours. A positive characteristic of the internal tourist market is the increase in the number of tour operators and travel agents, which increases the competition, stimulates the introduction of innovations and entry into foreign markets. In order to stimulate domestic demand for Ukrainian tourist products, the following measures are necessary:

- development of social tourism at the expense of Union funds;

- tracking changes taking place in the structure of foreign tourist demand, and adapting the offer on the internal market to these and expected subsequent changes;

- returning the existing rules on the application of the zero VAT rate to the export of tourist services;

- granting enterprises the right to include to the expenses the amounts paid by them to rest and rehabilitate their employees in domestic sanatoriums and rest homes when determining the object of taxation.

The third determinant is the presence in the country of supporting and related industries that are competitive in the global market. Thus, the sectors that directly or indirectly are engaged in the creation of a tourism product of Ukraine are the food and light industry, as well as the sphere of transport and hotel services. It is worthwhile to note that the food industry is on the 2nd and light - on 8th place by the contribution of the branches of Ukrainian industry to the total industrial production in Ukraine (Radeke, 2014). Mining, food industry and machine building are the dominant industries, the total contribution of which to the total gross value added in industry is almost $60 \%$. Structure of economic activities can be managed, especially in transition countries. The article (Vyklyuk et al., 2016) provides evidence about determining the future dynamics of the economic activities with increasing value added. It is worth noting that the overall negative trend of industrial decline in Ukraine in 2015 also affected related industries. If the production of food in 2014 showed an increase of $2.5 \%$, then in 2015 this industry showed a drop of $11.2 \%$ (Okrimen, 2016). In 2014, the fall in the production of light industry amounted to $1.4 \%$, and already in 2015 , the fall was $8.4 \%$ (Okhrimen, 2016). The latter happened, first of all, because of the decline in exports. Instead, the supply of the internal market by products of light and food industries is reported by the State Statistics Service as sufficient. This creates additional opportunities for the development of the main, that is, the studied sphere of tourism.

Transport and hotel services are characterized by a low level of competitiveness. The prices for services in hotels of Ukraine do not correspond to world standards and quality of the provided service. That is, the basic condition for the successful existence of the sphere of economy "price-quality" is not fulfilled. By the end of 2015288 hotels have received the "Star" category (Informational and analytical materials to parliamentary hearings, 2016). The analysis of the transport sector concluded that it is one of the most monopolized spheres of the Ukrainian economy, which objectively reduces the quality of services; outdated transport infrastructure; unsatisfactory quality of roads. 
In order to overcome the existing disadvantages, in addition to the already mentioned changes that need to be made for the establishment of tourism infrastructure, modernization of the transport system requires:

- construction of new roads, repair and reconstruction of already existing road surface;

- to equip the transport infrastructure with all the necessary tourist objects (roadside parking places, road signs, which should inform about tourist objects, routes, attractions and other elements of the tourist infrastructure of the region);

- to update the country's rail and bus fleet.

The fourth important determinant is the firm strategy, structure and rivalry, that is, the conditions prevailing in a certain sphere. The Ukrainian tourist market should be investigated in the following directions: the market of tour operators and the market of travel agents. As of 2016, 552 legal entities have a license for tour operator activities (Tourist activity in Ukraine, 2016). Today, the market of tour operators can be described as oligopolistic, since the main part is taken by several large enterprises ("Anex Tour", "Green Tour", "TUI Ukraine", "Travel Professional Group" and some others), forming the national tourist product, dictate prices for it and interact with foreign partners in the field of outsourcing. Meanwhile, the current situation on the market of travel agents is fundamentally different and characterized by harsh conditions of competition, since it is represented by a large number of enterprises engaged in the promotion and sale of tourism products formed by tour operators. By 2016, there are 2803 travel agents in Ukraine (Tourist activity in Ukraine, 2016). The main inhibiting factor is the low targeting on the creation and promotion of an internal tourist product.

In these conditions, the role of the chance in the realities of the tourism industry of our country and determining its competitiveness is manifested in the following:

- there is no initiative in developing new tourist products;

- low level of application of the latest technological advances in the maintenance and infrastructure for tourists;

- political conflict with Russia;

- the political and economic instability that exists in Ukraine hinders the development of internal and inbound tourism flows.

As to the role of government in shaping national advantages, it has the ability to influence each of the determinants. We can outline the positive impact on the tourism sector in Ukraine, which has already taken place:

- on factor conditions - through preferential terms of taxation of hotel complexes that were put into operation in the framework of Euro-2012;

- on demand conditions - since 2010 the real wage rate of the populations is constantly increasing;

- on the development of related and supporting industries - the government influenced by the policy of control over the establishment of prices for transportation and gasoline, as well as by abolishing the mandatory certification of hotel and catering services provided by tourists enterprises. This will reduce the financial pressure on business entities operating in the field of tourism services. However, the abolition of one of the methods of control and influence by the government can lead to a significant deterioration in the quality of domestic services, which today does not meet the established standards. Therefore, other levers of influence on the quality of tourist services should be developed and implemented: first of all, promotion of voluntary certification, increase of interest in conscious maintenance of the proper quality of services and the image of own trademark, introduction of accessible and efficient system of placement by users and consideration of reviews, complaints and recommendations;

- on the firm strategy, structure and rivalry - the government of our country 
practically did not have a positive impact through tax policy, antimonopoly legislation, stimulating investments for the development of the tourism sector of the country.

\section{CONCLUSIONS}

The application of the Porter Diamond Model for the analysis of the competitiveness of the Ukrainian tourism sector has made it possible to confirm the viability of the proposed method of studying the competitiveness of the tourism sector of countries in transition on the basis of the determination of braking and stimulating factors by four determinants of Porter diamond model offered in our work. We also managed to assess the current position of Ukraine in the international tourist services market and to identify measures to eliminate the braking factors.

Thus, today the tourism sector of Ukraine is only at the stage of formation, which determines the low degree of its competitiveness on the world market. However, the assessment of the competitiveness of the national tourist product of Ukraine, according to the proposed methodology, indicates a significant number of available factors, the skillful use of which will enable Ukraine to take its rightful place in the world market of tourist services in accordance with its potential. A positive point is the significant level of competition among firms-travel agents, the presence of major segments of the tourist market, the provision of tourism with national resources. But the effect of these factors is almost eliminated by the lack of financial resources that would lead to the formation of a group of factors - a modern tourist infrastructure with a high level of information and automation, as well as with a greater orientation of subjects of the tourist market of Ukraine to the internal and inbound tourists.

That is why we need to develop and detail the conceptual strategic directions for the development of the domestic tourism sector at a high level of competitiveness, and our further researches will be devoted to this.

\section{REFERENCES}

Barbosa, L., Oliveira, C., Rezende, C., (2010), Competitiveness of tourist destinations: the study of 65 key destinations for the development of regional tourism, Revista de Administração Pública, 44(5), pp.1067-1095.doi: https://dx.doi.org/10.1590/So034-76122010000500004.

Bejdyk, O., O., (2001), Recreation and tourism resources of Ukraine: methodology and methods of analysis, terminology, zoning, Kyiv, $395 \mathrm{p}$.

Bezugla, V., O, (2004), Analysis of competitiveness of regions Ukraine, Regional Economy, vol. 4(34), pp. 64-68.

Bosch, F., A., J. van den, and van Prooijen A., A., (1992), The Competitive Advantage of European Nations: The Impact of National Culture- a Missing Element in Porter's Analysis?, European Management Journal, vol. 10, No.2, p. 173-177.

Cappucci, M., (2016), Indigenous tourism in the Amazon region of Suriname: actions to preserve authenticity and natural resources, in Geo Journal of Tourism and Geosites, no. 1, pp. 47-56.

Curta, N., (2016), Competitiveness and performance in tourism. Case study for Romania, Quaestus Multidisciplinary Research Journal, Nr. 8, pp. 31-46. [online] Available at: < http://www.quaestus.ro/wp-content/uploads/2012/o3/curta.pdf > [Accessed 29 August 2017].

Dovbenko, O., M., (2007), Tax incentives of investments in the tourism sector of Ukraine, Bulletin of the KNEU "Formation of a Market Economy". Retrieved from: http://tourlib.net/statti_ukr/dovbenko3.htm.

Enright, M., Newton, J., (2004), Tourism destination competitiveness: a quantitative approach, Tourism Management, n. 25, pp. 777-788.

Gooroochurn, N., Sugiyarto G., (2004), Measuring competitiveness, Discussion Paper, TTRI, Nottingham University Business School. University of Nottingham.

Hrynkevych, A., A., Biel, M., M., (2009), Improving the competitiveness assessment of tourist product of the region, Regional Economy, vol. 4, pp. 40-46.

Koskovetskaya, N. M., Skorobogatova N.E., (2016), Industry competitiveness in the integration processes. Actual problems of economics and management, 10, [online] Available at: < http://ape.fmm.kpi.ua/ article /viewFile/66917/pdf_24> [Accessed 29 August 2017]. 
Melián-González, A., García-Falcón, J., M., (2003), Competitive potential of tourism in destinations, Annals of Tourism Research, v. 30, n. 3, pp.720-740.

Mihuschenko, Y., V., (2013), Methods of evaluating competitiveness of Ukraine tourism industry, Economy. Management, Innovation 1(9), pp. 39-56. doi: http://nbuv.gov.ua/j-pdf/eui_2013_1_39.pdf.

Okhrimen, A., (2016), The Ukrainian industry of 2015 is a really big riddle, Retrieved from: https://ua.112.ua/mnenie/ukrainska-promyslovist-2015-roku-tse-diisno-velyka-zahadka-287695.html

Porter, M., (1990), The Competitive Advantage of Nations, The Free Press, A Division of Macmillan, London.

Porter, M., (1998), The Competitive Advantage of Nations, The Free Press, New York, NY.

Radeke J., Kirchner R., Naumenko D., (2014), Industrial sector of Ukraine: analysis and recent trends, Technical Note [TN / 02/2014]. Retrieved from: http://www.ier.com.ua/files//publications/Policy _Briefing_Series /TN_02_2014_ukr.pdf

Ritchie, J., R., Brent, Crouch, Geoffrey I., (2010), A model of destination competitiveness/ sustainability: Brazilian perspectives, Revista de Administração Pública, 44(5), pp.1049-1066. doi: https://dx.doi.org/ 10.1590/ Soo34-76122010000500003.

Shulgina, L., (2005), Mega factors of marketing of tourist services of Ukrainian enterprises, Bulletin of KNTEU, Issue 1, pp.23-32.

Tkachenko, T., I., (2016), Sustainable Tourism Development: Theory, Methodology, Business Realities. Monograph, KNTEU, Kyiv, $463 \mathrm{p}$.

Tuzunkan, D., (2018), Undergraduate tourism students' perceptions and attitudes towards tourism industry: the case of Daejeon, South Korea, in GeoJournal of Tourism and Geosites, no. 1, pp. 103-111.

Vyklyuk, Y., Yevdokymenko, V., Yaskal, I., (2016), The proportions and rates of economic activities as a factor of gross value added maximization in transition economy, Scientific Annals of Economics and Business, Vol. 63, Issue 1, pp. 47-64. DOI: 10.1515/aicue-2016-0004

Wahogo, J., (2006), An Application of Porter's Diamond Model to Analyse Competitiveness of Kenya's Tourism Industry, Retrieved from: http://erepository.uonbi.ac.ke/bitstream/handle/11295/21413/Wahogo_An \%20Application\%20Of\%2oPorter\%20S\%20Diamond\%20Model\%20To\%20Analyse\%2oCompetitivenes s\%20Of\%20Kenya\%20S\%20Tourism\%20Industry.pdf?sequence=3

*** Capital investment in Ukraine for 2010-2016, State Statistics Service of Ukraine, Retrieved from: http://www.ukrstat.gov.ua.

*** Informational and analytical materials to the parliamentary hearings, (2016), Development of the tourism industry as an instrument of economic development and investment attractiveness of Ukraine, Retrieved from: http://komsport.rada.gov.ua/uploads/documents/30566.pdf.

*** Tourist activity in Ukraine, (2016), Statistical bulletins. State Statistics Service of Ukraine, Retrieved from: http://www.ukrstat.gov.ua.

*** Tourist streams in Ukraine for 2000-2015, Statistical bulletins. State Statistics Service of Ukraine, Retrieved from://www.ukrstat.gov.ua.

*** World Economic Forum, (2013), The Travel \& Tourism Competitiveness Report 2013, Reducing Barriers to Economic Growth and Job Creation. Geneva, Switzerland. doi: http://www3.weforum.org/docs/ WEF_TT_Competitiveness_Report_2013.pdf

*** World Economic Forum, (2015), The Travel \& Tourism Competitiveness Report 2015, Growth through Shocks, Geneva, Switzerland, doi: http://www3.weforum.org/docs/TT15/WEF_Global_Travel\& Tourism_Report_2015.pdf

*** World Travel \& Tourism Council, (2016), Travel \& Tourism Economic Impact 2016, Annual Update Summary, London, Retrieved from:https://www.wttc.org/-/media/files/reports/economic\%20impact\% 2oresearch/2016\%20documents/economic\%20impact\%20summary\%202016_a4\%20web.pdf

Submitted:

17.11.2017
Revised:

19.03.2018
Accepted and published online 21.03.2018 